\title{
Seasonal succession of phototrophic biofilms in an Italian wastewater treatment plant: biovolume, spatial structure and exopolysaccharides
}

\author{
Roberta Congestri ${ }^{1, *}$, Francesca Di Pippo ${ }^{1}$, Roberto De Philippis ${ }^{3}$, Isabella Buttino ${ }^{4}$, \\ Gaio Paradossi ${ }^{2}$, Patrizia Albertano ${ }^{1}$ \\ ${ }^{1}$ Department of Biology, and 2Department of Chemical Sciences and Technologies, University of Rome 'Tor Vergata', \\ Via della Ricerca Scientifica 1, 00133 Rome, Italy \\ ${ }^{3}$ Department of Agricultural Biotechnology, University of Florence, Piazzale delle Cascine 24, 50144 Florence, Italy \\ ${ }^{4}$ Laboratory of Ecophysiology, Stazione Zoologica 'A. Dohrn', Villa Comunale, 80121 Naples, Italy
}

\begin{abstract}
A multiphasic approach was applied to investigate the structural features of phototrophic biofilms that grow in a wastewater treatment plant (WWTP) at Fiumicino Airport (Rome, Italy). Seasonal variations in species composition, biomass and exopolysaccharides produced were analyzed by light (LM) and electron microscopy (SEM), high performance liquid chromatography (HPLC) and circular dichroism (CD). Phototroph contribution to the 3-dimensional structure of the biofilm and its development was assessed by confocal laser scanning microscopy. Analysis of biofilms grown on polypropylene slides showed a stable species composition; seasonal changes in biomass were mostly due to changes of major cyanobacterial and algal taxonomic groups. Extensive growth was evident on the range of artificial substrata that were implanted in the treatment plant. CD spectra and HPLC analyses of 2 operationally defined exopolysaccharide fractions extracted from samples scraped off the tank walls revealed that negatively charged heteropolysaccharides comprised most of the matrix and capsular components of the biofilms. Cytochemical staining distinguished between acidic and sulphated residues in the samples observed by LM. The data provide a new insight into the structural integrity and development of phototrophic biofilms in this hyper-eutrophic environment, indicating a potential use of autochthonous consortia in an environmentally sound tertiary water treatment alternative to conventional chemico-physical technologies.
\end{abstract}

KEY WORDS: Phototrophic biofilms · Exopolysaccharides $\cdot$ Cyanobacteria $\cdot$ Algae $\cdot$ Biovolume Confocal laser scanning microscope $\cdot$ Wastewater treatment plant

\section{INTRODUCTION}

Biomass attached at the interface between water and substrata interferes with many ecological, biogeochemical, and biotechnological and environmental engineering processes (Battin et al. 2003, Larson \& Passy 2005). This attached biomass is commonly called biofilm, is often heterogeneous and multi-layered, and may contain minerals or abiotic materials that are trapped by extracellular products within the biofilm or released from cells as the biofilm ages (Sutherland 2001). The structure of the biofilm is maintained by 'glue-like' extracellular polymeric substances (EPS) secreted by a variety of organisms (Stal 2000). Cyanobacteria and eukaryotic microalgae such as diatoms and green algae are the major phototrophic components of biofilms in freshwater ecosystems (Stevenson 1996).

Cyanobacteria secrete EPS as capsules and sheaths that surround cells and filaments as amorphous mucilage in the medium and also as slime for gliding motility (De Philippis \& Vincenzini 1998). Diatom EPS production is commonly associated with aggregation (physical coagulation; Thornton 2002) and colony formation (mucilage pads, fibrils etc.) in pelagic species 
and with substrate adhesion (stalks, tubes) and locomotion in benthic forms (Hoagland et al. 1993). Many representatives of green algae possess cellulose or glycoprotein cell walls and capsules (van den Hoek et al. 1995, Shubert 2003), several colonial forms are embedded in mucilage matrix, while mucilage is extruded by desmids for gliding (Nultsch \& Hader 1988). In addition, many planktic forms release dissolved organic material, which comprises a significant fraction of polysaccharides (Kaplan 1987, Lombardi \& Vieria 1999, Lombardi et al. 2005).

Overall, EPS are involved in adhesion to the substrata and cohesion between the cells of a biofilm; they play a role in surface-associated motility and provide protection against desiccation and grazing by predators, producing a matrix network that embeds cells and detritus (Wingender et al. 1999, Decho 2000). These exopolymers provide a microenvironment where UVabsorbing pigments and proteins, including enzymes, are immobilized (Sutherland 2001). The major components of the matrix are polysaccharides, but proteins and nucleic acids can comprise a significant part (Decho 2000). Extracellular polysaccharides may also serve in the immobilization and accumulation of noxious compounds, acting as a natural molecular sieve or an ion exchanger of xenobiotics and toxins; thus, the exploitation of biofilms may be particularly useful for bioremediation purposes (Craggs et al. 1996, Wingender et al. 1999). However, the potential application of spontaneously developing phototrophic biofilm in wastewater treatment plants (WWTP) has been largely neglected (Hoffmann 1998). In addition, there have been relatively few studies of the species composition and biomass production of these photosynthetic microbial communities (Davis et al. 1990a,b, Sládečková 1994, Sládečková \& Matulová 1998). Overall, little is known about the spatial organization, development or EPS characteristics of biofilms in out-door systems. It must be noted that EPS polysaccharide research in the field is often hampered by many external processes that interfere with their persistence in the environment, such as scouring, irreversible adsorption to sediment particles and degradation by various microorganisms. The situation is further complicated in that the EPS matrix originates from different organisms, producing more than one type of polymer that differ in saccharide unit composition and sequence (Neu 1994). The synthesis of these polymers may also significantly vary in response to environmental factors and cell status (De Philippis \& Vincenzini 1998, Staats et al. 1999, Smith \& Underwood 2000, de Brouwer et al. 2002, Otero \& Vincenzini 2004, Underwood et al. 2004, Barranguet et al. 2005, Stal \& Défarge 2005).

The aim of this study was to investigate the structural integrity, potential productivity and matrix polysaccharide characteristics of phototrophic biofilms colonizing a southern temperate WWTP (Fiumicino Airport WWTP, Rome, Italy). A variety of microscopic and chemico-physical techniques were used to determine seasonal changes in samples taken directly from the WWTP tank walls (providing high biomass for exopolysaccharide studies) or from immersed polypropylene slides (for biovolume estimates). Non-destructive sampling of biofilm material for confocal light scanning microscope (CLSM) was achieved by hanging artificial substrata in the overflow system of the tank.

\section{MATERIALS AND METHODS}

The Fiumicino WWTP (Leonardo da Vinci Airport) is an out-door system designed to process municipal wastewaters with an estimated inflow and outflow of $6000 \mathrm{~m}^{3} \mathrm{~d}^{-1}$, and uses oxygen injections in the primary tank and constant stirring in the secondary tank to reduce biological oxygen demand (BOD).

Samples were collected seasonally (May, August, November 2001; February, May and August 2002; Table 1) by scraping biofilms from the concrete walls of the sedimentation tank (ST) and from immersed polypropylene slides. Two slides $(8 \times 3 \mathrm{~cm})$ were placed on the ledge of the tank (northwest unshaded side) below the weirs of the overflow system (water depth 1 to $2 \mathrm{~cm}$ ) for $1 \mathrm{wk}$ to allow colonization. For CLSM analyses of biofilm structure, intact communities were examined on 3 different artificial substrata, immersed as described above, for 1 or 2 wk in May, August, November 2001 and February 2002 (Table 1).

Phototrophic composition and biomass. Biofilms were scraped off the polypropylene slides after incuba-

Table 1. Summary of sampling and analysis conducted during the study. TW: tank walls; AS: artificial substrata; CD: circular dichroism; Cytochem: cytochemical staining of exopolysaccharides; Biovolume: calculation of biovolume; CLSM: confocal light scanning microscopy; LM: light microscopy; SEM: scanning electron microscopy

\begin{tabular}{|ccccccc|}
\hline & May 01 & Aug 01 & Nov 01 & Feb 02 & May 02 & Aug 02 \\
\hline TW & & & CD & CD & CD & CD \\
& & & Cytochem & $\begin{array}{c}\text { HPLC } \\
\text { Cytochem }\end{array}$ & $\begin{array}{c}\text { HPLC } \\
\text { Cytochem }\end{array}$ & $\begin{array}{c}\text { HPLC } \\
\text { Cytochem }\end{array}$ \\
AS & Biovolume & Biovolume & Biovolume & Biovolume & & \\
& CLSM/LM & CLSM/LM & CLSM/LM & CLSM/LM & & \\
& SEM & SEM & SEM & SEM & & \\
& & & & & & \\
\hline
\end{tabular}


tion in the ST for $1 \mathrm{wk}$ periods. The period of immersion was chosen to allow a similar period of colonization on the artificial substrata as on the tank walls. The tank walls were routinely brushed to remove biofilms at weekly intervals. Preliminary studies were made to determine the area required to incorporate total variation of the community comprising the biofilm. Macroscopically, it was not possible to observe any variation and the samples appeared to be homogenous. Microscopic observations of intact biofilms using CLSM revealed some patchiness; however, this was on a micro-scale. It was therefore decided to take $1 \mathrm{~cm}^{2}$ scrapings from the slides for 2 reasons: to safely incorporate all possible variation within biofilms, and to reduce any error in obtaining a quantitatively accurate sample. The sampled biofilms were suspended in $0.1 \mathrm{M}$ phosphate buffer ( $\mathrm{pH} 7.2$ ), fixed in $2 \%$ formaldehyde and $2.5 \%$ glutaraldehyde, and stored at $4{ }^{\circ} \mathrm{C}$.

Fixed samples were examined using a Zeiss Axioskop light microscope equipped with differential interference contrast (DIC) and $40 \times$ and $100 \times$ objectives. Further ultrastructural studies for diatom identification were conducted on acid-cleaned material (von Stosch 1974) using scanning electron microscopy (SEM; Philips XL30 field emission scanning microscope) at $5.0 \mathrm{kV}$.

To determine estimates of cell biovolume, the scrapings were sonicated twice for $3 \mathrm{~min}$ in a sonic water bath in order to disaggregate and homogenize the samples. Aliquots of sonicated suspensions were appropriately diluted in phosphate buffer and left to settle for $24 \mathrm{~h}$ in $25 \mathrm{ml}$ counting chambers. Observations were performed using a Nikon Eclipse Te200 inverted microscope with a $40 \times$ objective. Image analysis equipment (Nikon CoolSnap video-camera and LUCIA software) was used to acquire optical fields and digital images. Semi-automated measurements of selected morphometric parameters were used to estimate the biovolume of single cells using standardized equations (Hillebrand et al. 1999).

Biofilm architecture. Polypropylene slides, Whatman Anodisc filters and coverslips were used to visualize structure and seasonal development of intact biofilms on different substrata. Two periods of immersion ( 1 or $2 \mathrm{wk}$ ) were chosen to analyze the temporal succession and development of biofilms. The substrata were retrieved and immediately fixed with $2 \%$ formaldehyde spreading fixative with a syringe in a Petri dish. Observations were conducted using a Zeiss LSM 410 CLSM equipped with an argon ion laser and 10,25 and $40 \times$ objectives. Visualization of spatial distribution of phototrophs, biofilm development and architecture was achieved at the excitation wavelength of chl a (488 nm with emission at 575 to $650 \mathrm{~nm}$ ). Optical sections, taken at different depth of the biofilms, were acquired and combined using the Zeiss software package LSMDummy to obtain vertical reconstruction of samples.

Extraction of extracellular polysaccharides. The extraction of extracellular polysaccharides was conducted following Bellezza et al. (2003). Biofilm samples of about $1000 \mathrm{~g}$ were scraped off the ST walls and centrifuged at $8000 \mathrm{rpm}$ for $60 \mathrm{~min}$ (J2-21 Beckman centrifuge) to concentrate the sample. The resulting pellet, comprising the microorganisms and their envelopes (namely the 'capsular' [CPS] or 'bound polysaccharides'), was then separated into 2 fractions. One fraction was re-suspended in phosphate buffer $(\mathrm{pH} 7,1: 10$ volume) and incubated at $4^{\circ} \mathrm{C}$ for $7 \mathrm{~d}$. The suspension was then centrifuged (8000 rpm for $15 \mathrm{~min}$ ) and the supernatant precipitated in absolute EtOH (1:1 volume). After further centrifugation (14000 rpm for $60 \mathrm{~min}$ ), the pellet was re-suspended in distilled water. Finally, the supernatant was dialyzed against EDTA (0.01 M) and $\mathrm{NaCl}(0.5 \mathrm{M})$ for $2 \mathrm{~h}$ and then against distilled water for $4 \mathrm{~d}$. This procedure is referred to as 'cold extraction', and generated a cold extracted capsular polysaccharide fraction (CPSc). The second fraction of the initial pellet was at first re-suspended in distilled water (1:10) and incubated at $80^{\circ} \mathrm{C}$ for $60 \mathrm{~min}$. Dialysis (as above) proceeded this 'hot extraction' and the obtained extract was operationally referred to as CPSh.

Monosaccharide composition. Lyophilized CPSc and CPSh samples were analyzed for their monosaccharide composition after hydrolysis with $2 \mathrm{~N}$ trifluoroacetic acid $\left(120^{\circ} \mathrm{C}\right.$ for $\left.45 \mathrm{~min}\right)$, according to the HPLC method described by Vincenzini et al. (1990a).

Circular dichroism analyses. CPSc and CPSh samples were analyzed by circular dichroism (CD) in order to investigate transition of polysaccharide molecular conformations as a function of $\mathrm{pH}$ and temperature, using a Jasco Spectropolarimeter J600 equipped with quartz cells of $0.1 \mathrm{~cm}$, an optical path-length primarily in the UV spectral region (200 to $300 \mathrm{~nm}$ ) and between 200 and $270 \mathrm{~nm}$ (20 $\mathrm{nm} \mathrm{min}^{-1}$ scanning velocity), and the original Jasco software. The $\mathrm{pH}$ of the 2 fractions was first decreased with $\mathrm{HClO}_{4}(0.02 \mathrm{M})$ and then increased with $\mathrm{NaOH}(0.02 \mathrm{M})$. The $\mathrm{pH}$ values were measured using a calibrated digital combined $\mathrm{pH}-$ meter (Amel Instrumments, 334-B). Temperature of the 2 fractions was increased from 25 to $60^{\circ} \mathrm{C}$ in single increments of 5 to $10^{\circ} \mathrm{C}$, and was achieved using a thermostat (Lauda M3)-controlled cell holder.

Exopolysaccharide cytochemistry. Biofilm samples were scraped off the tank walls for light microscopy (LM) observation (Zeiss Axioskop) after cytochemical staining using (1) Alcian Blue (AB) at pH 0.5 and 2.5 to visualize the sulphated and carboxylated groups, respectively, and (2) Ruthenium Red (RR) to observe the acidic polysaccharides (Albertano \& Bellezza 2001). 


\section{RESULTS}

\section{Composition and seasonal distribution of phototrophic biomass}

Phototrophs constituted the major components of biofilms grown seasonally on polypropylene slides immersed for $1 \mathrm{wk}$ periods in the Fiumicino WWTP ST. These phototrophs were essentially composed of cyanobacteria, diatoms and green algae (Table 2). Observations of the phototrophic community composition were based on species identifications from previous studies of biofilms in these tanks (Albertano et al. 1999, Congestri et al. 2003, 2005). A variety of Chroococcalean cyanobacteria, either unicellular or colonial forms, were distinguished along with 6 Oscillatorialean taxa mostly belonging to Oscillatoria and Phormidium spp. In total, 15 diatom taxa were identified. Raphid forms prevailed, with only 1 centric (Cyclotella meneghiniana Kützing) and 1 araphid

Table 2. Biovolume of individual taxa observed on polypropylene slides during different seasons. Data expressed as $\times 10^{6} \mu^{3} \mathrm{~cm}^{-2}$

\begin{tabular}{|c|c|c|c|c|}
\hline Taxon & May 01 & Aug 01 & Nov 01 & Feb 02 \\
\hline \multicolumn{5}{|l|}{ Cynaobacteria: } \\
\hline Arthrospira jenneri & & & & 45.73 \\
\hline Oscillatoria limosa & 205.38 & 44.59 & 18.27 & 200.31 \\
\hline Oscillatoria tenuis & 72.37 & 23.92 & 1.54 & 237.00 \\
\hline Phormidium nigrum & 254.98 & & 31.56 & 27.30 \\
\hline Phormidium pseudacutissimum & 29.69 & & 1.54 & \\
\hline Phormidium sp. & & 58.76 & 2.60 & \\
\hline Chroococcal cyanobacteria & & 3.21 & & \\
\hline \multicolumn{5}{|l|}{ Bacillariophytes: } \\
\hline Achnanthes exigua & & 8.35 & 2.69 & \\
\hline Craticula accomoda & 0.30 & 13.85 & & \\
\hline Craticula cuspidata & & & 0.54 & 5.99 \\
\hline Cyclotella meneghiniana & 40.26 & 360.51 & 20.11 & 0.67 \\
\hline Diadesmis confervacea & 10.59 & 37.49 & 4.32 & \\
\hline Eolimna subminuscula & & & 1.67 & \\
\hline Gomphonema parvulum & 0.34 & 2.93 & 1.04 & \\
\hline Navicula gregaria & 2.28 & 1.05 & 9.82 & 0.31 \\
\hline Nitzschia amphibia & 0.50 & 1.30 & 0.46 & \\
\hline Nitzschia palea var. minuta & 65.41 & & 0.32 & 40.64 \\
\hline Nitzschia palea var. debilis & 165.43 & 72.89 & 32.13 & 11.56 \\
\hline Nitzschia umbonata & 366.91 & 19.76 & 5.64 & 193.99 \\
\hline \multicolumn{5}{|l|}{ Pinnularia gibba } \\
\hline Sellaphora pupula & & 15.90 & 13.12 & 1.86 \\
\hline Staurosira pinnata & & & 2.21 & \\
\hline \multicolumn{5}{|l|}{$\begin{array}{l}\text { Xanthophytes: } \\
\text { Tribonema sp. }\end{array}$} \\
\hline \multicolumn{5}{|l|}{ Chlorophytes: } \\
\hline Chlorococcum sp. & 13.18 & 12.73 & 46.16 & 5.78 \\
\hline Desmodesmus sp. & 0.12 & 11.74 & & \\
\hline Pseudococcomyха sp. & 0.14 & 2.32 & 0.92 & \\
\hline Sphaerocystis sp. & & 7.44 & 17.48 & \\
\hline Stigeoclonium sp. & & 5.34 & & \\
\hline \multicolumn{5}{|l|}{ Euglenophytes: } \\
\hline Euglena sp. & 123.46 & 6.49 & 19.37 & 9.74 \\
\hline
\end{tabular}

(Staurosira pinnata Ehrenberg) form identified. SEM analysis of acid-cleaned material allowed confirmation of species identities. Diatom assemblages within biofilms often encompassed large naviculoid forms that were readily recognizable under an inverted microscope from their dimensions and chloroplast morphology. The small diatoms $(<10 \mu \mathrm{m})$ Eolimna subminuscula (Manguin) Moser et al. and Staurosira pinnata were also present, but identification of these species was only possible using SEM (Figs. 1 \& 2). Representatives of green algae (mostly Chlorophyceae) were also observed in the seasonal samples, with Chlorococcum sp. and Coelastrum sp. prevailing.

Maximum total biovolume $\left(1351.54 \times 10^{6} \mathrm{\mu m}^{3} \mathrm{~cm}^{-2}\right)$ was recorded in spring (May 2001, Fig. 3), when there was a co-dominance of raphid diatoms ( $48 \%$ total phototrophic biovolume) and oscillatorialean cyanobacteria (42\%): a prevalence of Nitzschia umbonata (Ehrenberg) Lange-Bertalot and N. palea var. minuta Bleish was observed within the former taxonomic group, and Phormidium nigrum (Vaucher ex Gomont) Anagnostidis et Komarek and Oscillatoria limosa Agardh within the latter (Table 2, Fig. 3). The summer (August 2001) assemblage was largely dominated by diatoms that constituted up to $75 \%$ of total biomass, but on this occasion the centric Cyclotella meneghiniana prevailed markedly. In autumn (November 2001), the contribution of diatoms was still significant $(40 \%)$, while green algae (especially coccal forms) and cyanobacteria contributed 28 and $24 \%$ to total phototrophic biovolume, respectively. Cyanobacteria were prevalent in winter (February 2002), representing $65 \%$ of total phototrophic biovolume, with the majority of observed biomass being comprised of Arthrospira jenneri Stizenberg, Phormidium nigrum, $O$. limosa and $O$. tenuis Agardh. These cyanobacteria were typically associated with various raphid diatoms that mostly belonged to Nitzschia species, namely N. palea var. debilis Kützing et Grunow and N. umbonata.

\section{Biofilm architecture}

CLSM observations of intact biofilms grown on the 3 artificial substrata revealed similar assemblages that had reached a degree of com- 

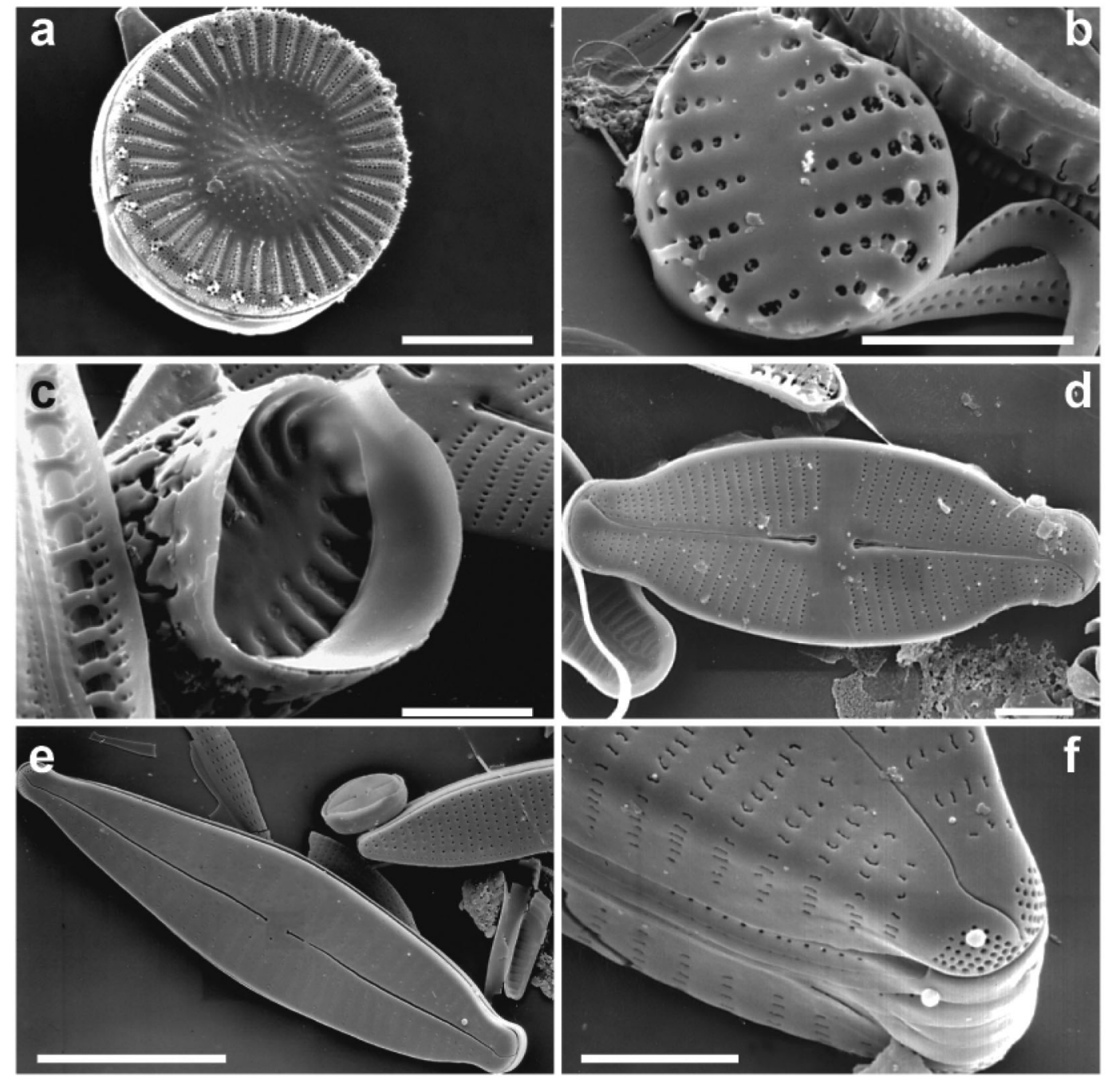

Fig. 1. SEM micrographs of (a) Cyclotella meneghiniana, external view; (b,c) Staurosira pinnata (b) outer and (c) inner valve surface; (d) Achnanthes exigua, external view; and (e,f) Gomphonema sp. (e) outer surface and (f) detail of the apical pore field. Scale bars: (a) $5 \mu m_{i}(b, c, d, f) 2 \mu m_{i}$ (e) $10 \mu \mathrm{m}$

plexity within $7 \mathrm{~d}$. Maximum biofilm thickness after a 2 wk incubation period $(\sim 260 \mu \mathrm{m})$ was recorded in autumn (November 2001) on polypropylene slides. No obvious taxonomic or structural differences were observed among assemblages grown on the substrata tested; however, spatial distribution of organisms was relatively more patchy on coverslips owing to the sloughing of filamentous and ramified forms. The colonization of each substratum normally resulted in patches of differing thickness, and combined epifluorescence and transmitted light observations also revealed the presence of voids. The mature, 1 wk-old communities exhibited obvious developmental stratification of microorganisms (Fig. 4a,b). This exposure time allowed development of forms sometimes adherent and parallel to the substratum (adnate diatom forms such as Achanthes spp., other diatoms,
Cyclotella meneghiniana, and the coccal green alga Chlorococcum sp.), followed by erect, sessile taxa (stalked diatom species such as Gomphonema spp. and Encyonema minutum [Hilse] D. G. Mann, and filamentous and/or ramified green algae as Stigeoclonium sp. and Cladophora sp.). Tangled within these fixed forms were the chain-forming diatoms Diadesmis confervacea Kützing and Staurosira pinnata, in addition to filamentous oscillatorialean cyanobacteria. Motile diatoms such as Craticula accomoda (Hustedt) D.G. Mann, Navicula gregaria Donkin and Nitzschia spp. were interspersed in the biofilms, either occupying the very inner or the outermost layers. The 2 wk-old communities showed full complexity and horizontal heterogeneity. There were more microorganisms colonizing the substrata than were recorded in the $1 \mathrm{wk}$-old community, and strati- 

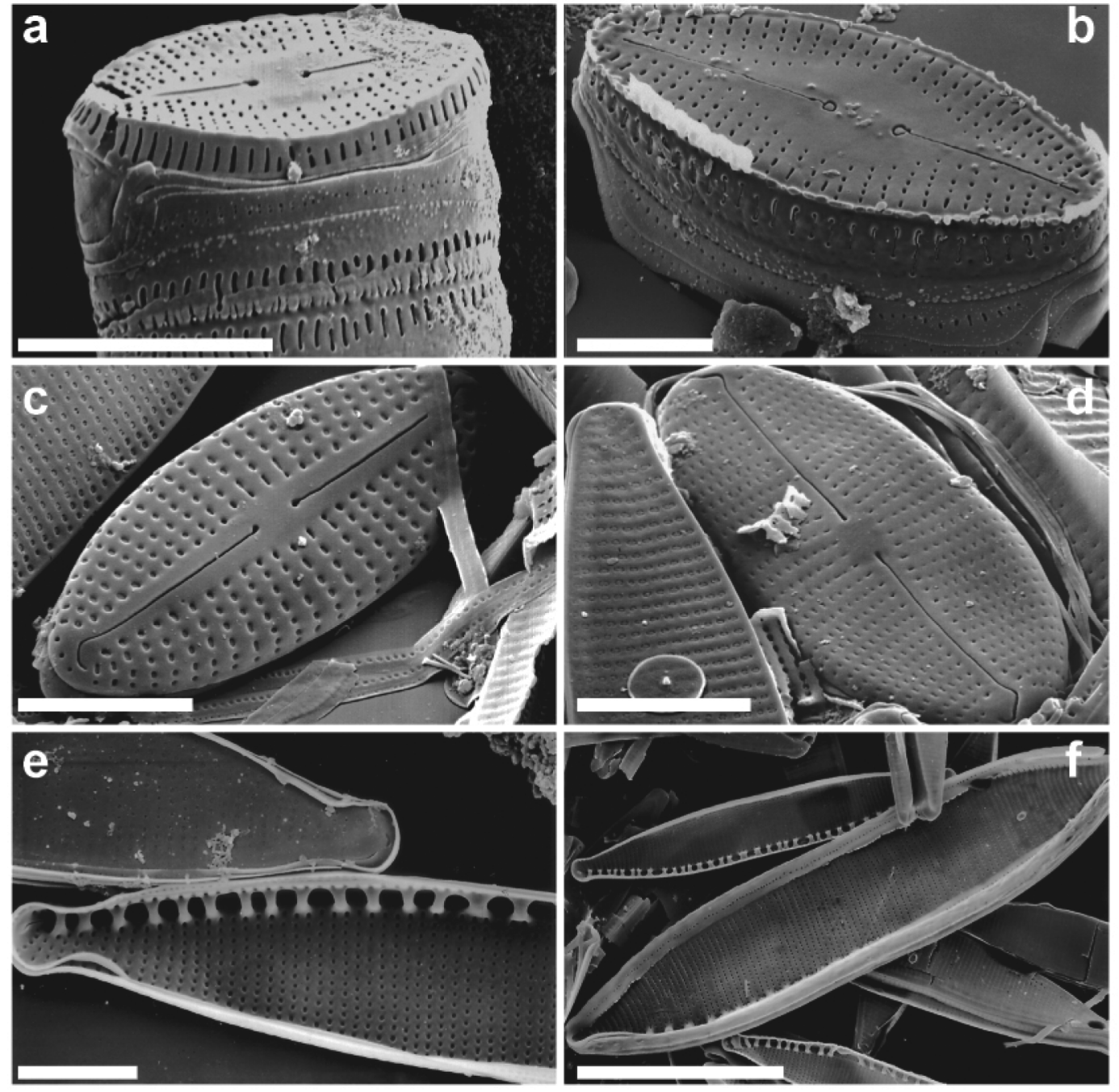

Fig. 2. SEM micrographs of (a,b) Diadesmis confervacea, (a) girdle view and (b) outer valve surface; (c) Eolimna subminuscula, external view; (d) Craticula accomoda, external view; (e) Nitzschia palea var. minuta apical areas in external and internal view; and (f) Nitzschia umbonata larger valve, internal surface. Scale bars: (a) $5 \mu \mathrm{m}$; (b,c,d,e) $2 \mu \mathrm{m}$; (f) $10 \mu \mathrm{m}$

fication and successional stages were apparent (from adherent forms to sessile, epiphytic taxa; Fig. 4c,d). However, this was not evident in winter biofilms grown on any type of substrate, which were characterized by very low diversity and low stratification (Fig. 4e,f). Seasonal variation in the architecture of the biofilm reflected changes in the compositional patterns: the highest degree of complexity, spatial heterogeneity and layering in phototroph distribution was observed in November 2001.

\section{Exopolysaccharide cytochemistry}

Light microscopy after cytochemical staining of samples scraped off tank walls showed that there were sulphated $(\mathrm{AB}, \mathrm{pH} 0.5)$ carboxylated $(\mathrm{AB}, \mathrm{pH} 2.5)$ and acidic groups (RR) present in the biofilm (Table 3). AB $\mathrm{pH} 0.5$ treatment did not reveal sulphated residues in chroococcal cyanobacteria, whereas 2 oscillatorialeans (Lyngbya cf. martensiana Meneghini and Phormidium insigne [Skuja] Anagnostidis et Komarek) gave a positive reaction. Sulphated groups were found in all diatoms, but were absent from the green algae. $\mathrm{AB} \mathrm{pH}$ 2.5 staining revealed carboxyl groups in the envelopes of all chroococcalean and in about $50 \%$ of oscillatorialean cyanobacteria. $\mathrm{COOH}$ residues were not present in the green algae, but they were present in all diatoms, except for the 2 varieties of Nitzschia palea. RR treatment revealed acidic polysaccharides for all chroococcalean cyanobacteria, in about $50 \%$ of oscillatorialean forms, and in all the diatoms except Cyclotella meneghiniana and Navicula gregaria. Green algae did not give a positive reaction to RR. 

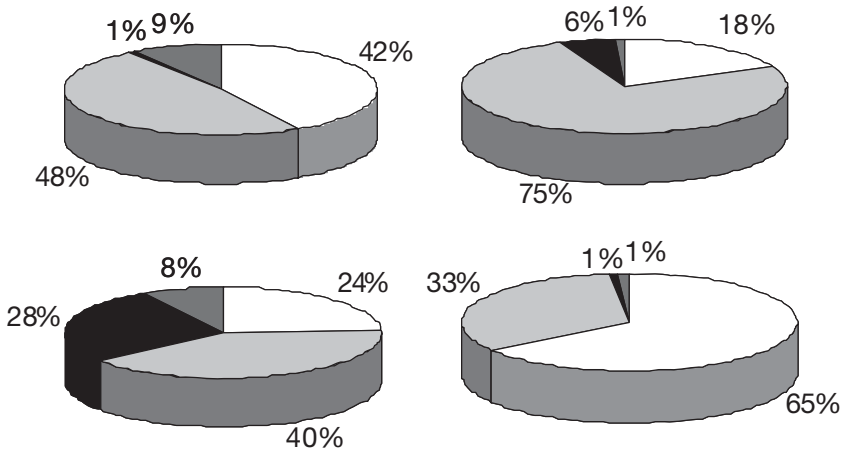

$\square$ Cyanobacteria $\square$ Diatoms

- Green algae $\square$ Euglena sp.

Fig. 3. Contribution (\%) of major taxonomic groups to total phototroph biovolume in seasonal biofilm samples scraped off polypropylene slides

\section{Extracellular monosaccharide composition}

All fractions contained various proportions of 6 different neutral monosaccharides and at least 1 uronic acid (Table 4). In February, galactose was the main sugar in both fractions, followed by mannose in the CPSh and by galacturonic acid in the CPSc. The latter sugar was not found in the CPSh. In May, the contribution of galactose decreased in both fractions, whereas concentrations of glucose and of fucose and rhamnose were prevalent in the CPSh and $\mathrm{CPSc}$, respectively. The CPSc fraction contained the highest amount of glucuronic acid in all the polymers analyzed, whereas this sugar was not present in the CPSh. In contrast, the CPSh contained galacturonic acid, which was not detected in the CPSc. Both uronic acids were present in August, with a high contribution of galacturonic
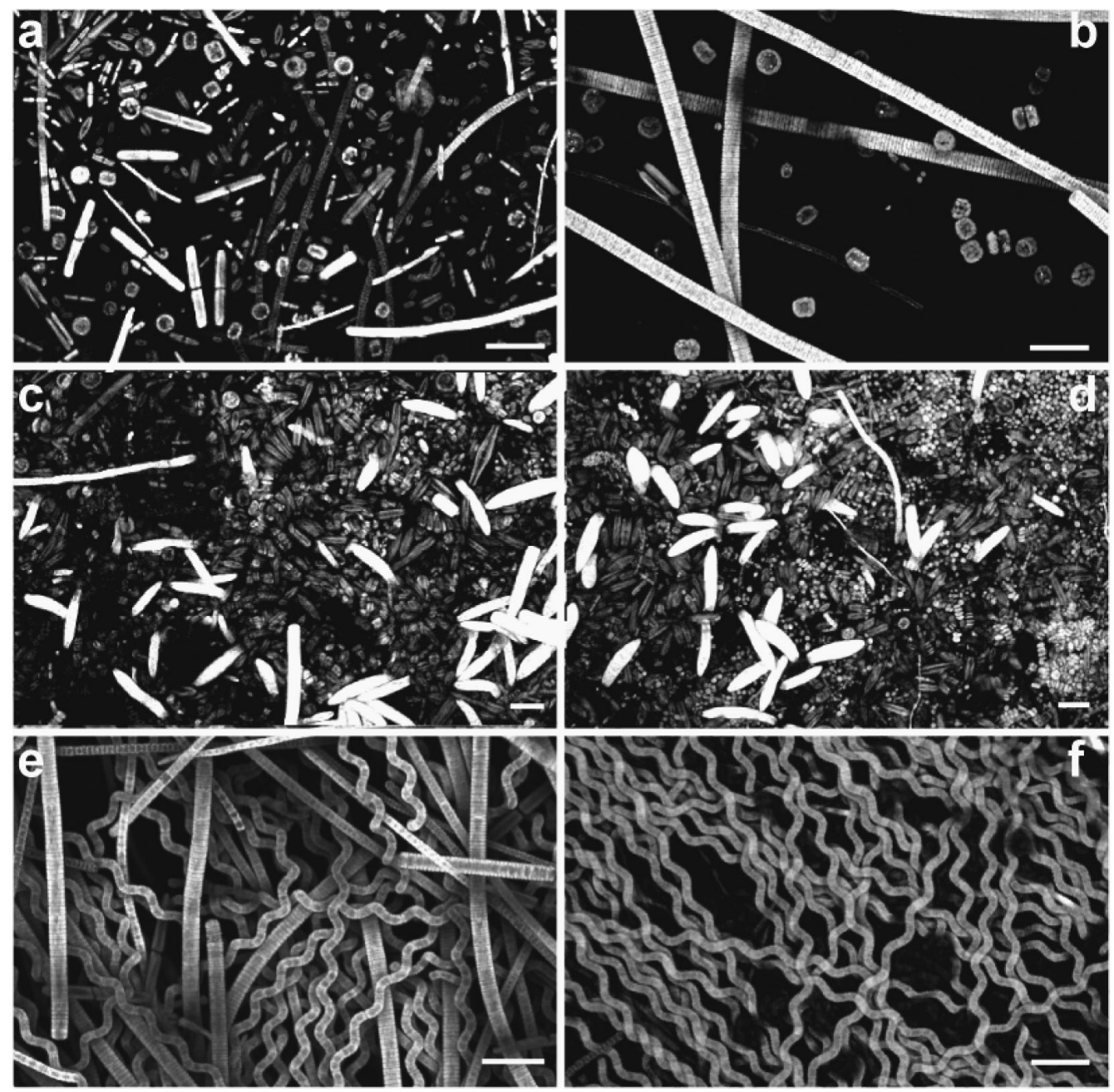

Fig. 4. Confocal light scanning microscope images illustrating vertical reconstructions of biofilms on artificial substrata. November samples grown for $1 \mathrm{wk}$ on (a) polypropylene slides and (b) coverslips, with voids visible; 2 wk stratified biofilms from (c) summer and (d) autumn samples, and winter communities dominated by cyanobacteria on (e) polypropylene slides and (f) Anodisc membrane filters. Scale bars: $30 \mu \mathrm{m}$ 
Table 3. Cytochemistry results obtained for main phototrophic taxa present in biofilms scraped off tank walls. AB: Alcian Blue; RR: Ruthenium Red; +: positive reaction; -: no reaction

\begin{tabular}{|c|c|c|c|}
\hline \multirow{2}{*}{ Taxon } & \multicolumn{3}{|c|}{ Stain } \\
\hline & AB pH 0.5 & AB pH 2.5 & RR \\
\hline \multicolumn{4}{|l|}{ Cyanobacteria: } \\
\hline Arthrospira jenneri & - & + & + \\
\hline Arthrospira sp. & - & - & - \\
\hline Chroococcus obliteratus & - & + & + \\
\hline Chroococcus vacuolatus & - & + & + \\
\hline Komvophoron sp. & - & - & - \\
\hline Leptolyngbya sp. & - & + & + \\
\hline Lyngbya cf. martensiana & + & + & + \\
\hline Oscillatoria limosa & - & - & + \\
\hline Oscillatoria tenuis & - & + & + \\
\hline Phormidium carotinosum & - & - & - \\
\hline Phormidium insigne & + & + & + \\
\hline Phormidium laetevirens & - & - & - \\
\hline Phormidium pseudacutissimun & um - & - & - \\
\hline Pseudoanabaena catenata & - & + & + \\
\hline Pseudoanabaena mucicola & - & - & - \\
\hline Synechocystis aquatilis & - & + & + \\
\hline \multicolumn{4}{|l|}{ Bacillariophytes: } \\
\hline Cyclotella meneghiniana & + & + & - \\
\hline Diadesmis confervacea & + & + & + \\
\hline Gomphonema parvulum & + & + & + \\
\hline Gomphonema sp. & + & + & + \\
\hline Navicula gregaria & + & + & - \\
\hline Nitzschia palea var. minuta & + & - & + \\
\hline Nitzschia palea var. debilis & + & - & + \\
\hline Nitzschia umbonata & + & + & + \\
\hline Sellaphora pupula & + & + & + \\
\hline \multicolumn{4}{|l|}{ Chlorophytes: } \\
\hline Chlorococcum sp. & - & - & - \\
\hline Desmodesmus sp. & - & - & - \\
\hline Pseudococcomyха sp. & - & - & - \\
\hline Scenedesmus obliquus & - & - & - \\
\hline \multicolumn{4}{|l|}{ Euglenophytes: } \\
\hline Euglena sp. & - & + & - \\
\hline
\end{tabular}

Table 4. Monosaccharide composition of capsular polysaccharides obtained after cold (CPSc) and hot (CPSh) extraction. Data expressed as mol (\%). GlcA: glucuronic acid; GalA: galacturonic acid; Gal: galactose; Glc: glucose; Man: mannose; Ara: arabinose; Fuc: fucose; Rha: rhamnose

\begin{tabular}{|c|c|c|c|c|c|c|}
\hline \multirow{2}{*}{$\begin{array}{l}\text { Monosac- } \\
\text { charide }\end{array}$} & \multicolumn{2}{|c|}{ Feb 02} & \multicolumn{2}{|c|}{ May 02} & \multicolumn{2}{|c|}{ Aug 02} \\
\hline & CPSc & CPSh & CPSc & CPSh & CPSc & CPSh \\
\hline GlcA & 3.3 & 3.1 & 5.8 & 0 & 2.6 & 1.3 \\
\hline GalA & 21.7 & 0 & 0 & 3.2 & 14.4 & 5 \\
\hline Gal & 22.9 & 23.8 & 17.3 & 17.7 & 23.3 & 22.7 \\
\hline Glc & 14.1 & 11.8 & 5.3 & 20.2 & 14.4 & 16.9 \\
\hline Man & 6.9 & 21.7 & 13.4 & 10.5 & 5.5 & 10.9 \\
\hline Ara & 9.4 & 13.2 & 17 & 19 & 15.3 & 23.4 \\
\hline Fuc & 11.5 & 13.2 & 21.2 & 13.3 & 13.8 & 9.5 \\
\hline Rha & 10.2 & 13.2 & 20 & 16.1 & 10.7 & 10.3 \\
\hline
\end{tabular}

acid to the CPSc. In addition, galactose appeared to dominate both fractions, as was observed in the January samples; however, the amount of arabinose in the CPSh was slightly higher.

\section{Circular dichroism (CD) analyses}

CD spectra of capsular polysaccharide fractions extracted in different seasons revealed the absence of ellipticity in the region between 270 and $300 \mathrm{~nm}$, typically indicative of the presence of tryptophan and phenyl alanine aminoacid residues; however, ellipticity was always observed in the spectral region from 200 to $250 \mathrm{~nm}$ (Fig. 5a,b). Variable temperature did not affect any of the recorded spectra, but short-range conformational thermal fluctuations (not detectable using this method) cannot be excluded (Fig. 5c). Conversely, variable $\mathrm{pH}$ affected the $\mathrm{CD}$ spectra of all samples tested (Fig. 5d).

\section{DISCUSSION}

The seasonal change in community composition was relatively stable and characterized by low species diversity. However, the proportional contributions of individual species varied seasonally. In situ observations of biofilm communities at this site, made between 1998 and 2005, revealed an almost constant successional pattern every year that possibly resulted from the stable chemical characteristics of the water (Congestri et al. 2003, 2005). It therefore seems that the seasonal change in community structure is driven by changes in temperature and light regime (Albertano et al. 1999). Community composition was similar to that of eutrophic, organically polluted water bodies (such as other WWTPs; Davis et al. 1990a, Sládečková \& Matulová 1998).

Seasonal variations in biomass were observed during this study; furthermore, total biovolume was around 5 times greater in spring than in autumn, owing to the contribution of large diatoms that were abundant in spring (Congestri et al. 2005). Overall, biovolume data indicated that this outdoor system supported extensive phototrophic growth (high biomass productivity) in comparison with natural lentic systems (Lam \& Lei 1999) and other WWTPs situated in cooler climatic areas (Davis et al. 1990b).

Examination using CLSM revealed that the communities that developed over 1 wk had a complex, stratified structure, which was most evident in August and November. Cross-sectional observations of the biofilm showed a succession of diatom life-forms, from those that lie parallel to the substratum to erect (sessile and epiphytic) forms. Motile species were interspersed among these, and diatom succession was thus similar to the developmental sequence of attached diatom communities in Lake Biwa (Tuji 2000a,b). The colonization of the substratum by green algae was similar to that of diatoms, starting from species bearing a 


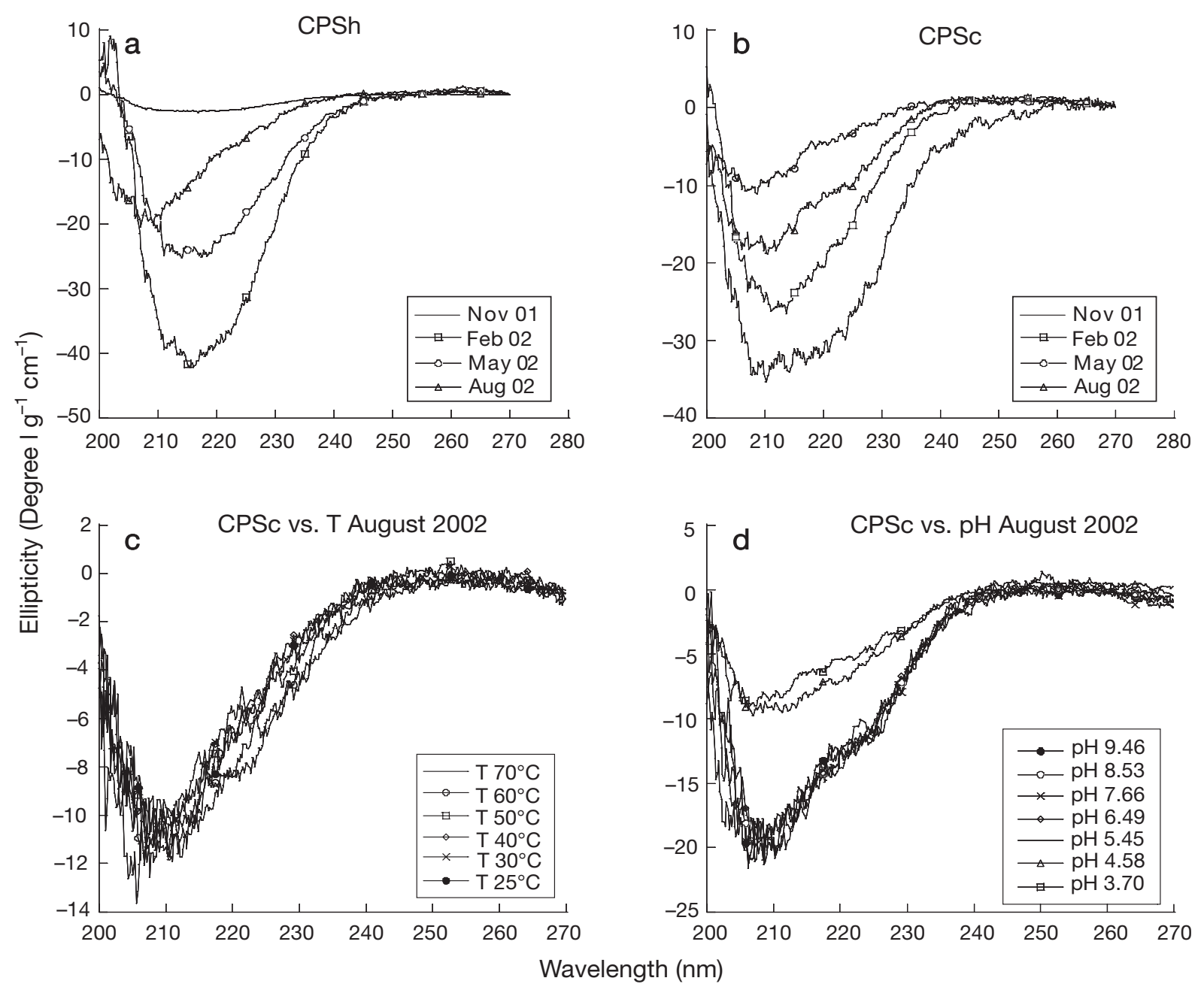

Fig. 5. Dichroic spectra of aqueous solution of capsular exopolysaccharides (CPS) obtained after (a) hot (CPSh) and (b) cold (CPSc) extraction at room temperature and neutral $\mathrm{pH}$. Dichroic spectra of aqueous solution of CPSc fractions analysed at different (c) temperature (T) and (d) pH. A dependence of ellipticity on $\mathrm{pH}$, especially at 3.70 and 4.58 values, is visible

mucilaginous layer on the cell surface (Chlorococcum and Scenedesmus spp.) followed by more complex, filamentous and ramified sessile forms. A true layering of the cyanobacterial biofilm fraction was not observed, but it must be stressed that filamentous cyanobacteria are capable of vertical movements in microbial aggregates in response to a range of environmental stimuli, especially light (Wiggli et al. 1999). When the phototrophic community was poorly diverse and dominated by filamentous cyanobacteria, as in February 2002, there was no observed vertical stratification in microbial distribution. On that occasion there was a marked prevalence among diatoms of the large, motile Nitzschia spp., indicative of the low irradiance experienced in winter (A. Guzzon \& P. B. Albertano pers. comm.). Comparisons of the colonization of different substrata indicated that the WWTP biofilm community is composed of generalist species that are able to actively proliferate on a range of artificial substrata.
Carbohydrates of the 2 extracted polysaccharide fractions (CPSh and CPSc) were composed of complex heteropolymers that contained at least 7 different sugars, both neutral and acidic. This agrees with findings on the composition of exopolysaccharides synthesized by a variety of cyanobacterial (De Philippis \& Vincenzini 1998, De Philippis et al. 2001) and diatom strains (de Winder et al. 1999, Staats et al. 1999, de Brouwer et al. 2002, Underwood et al. 2004). In cyanobacteria as a whole, dominant sugars are glucose, galactose, mannose, rhamnose, a range of pentoses that are normally absent from polysaccharides of other prokaryotes, and uronic acids, namely glucuronic and galacturonic acid (Gloaguen et al. 1995, De Philippis \& Vincenzini 1998, Nicolaus et al. 1999, Vincenzini et al. 1990a,b, Otero \& Vincenzini 2004). The exopolysaccharides of cultured diatoms are generally composed of galactose, mannose, rhamnose, uronic acids and sulphated sugars; there are only a few reports of polymers consisting mainly of glu- 
cose (Hoagland et al. 1993, de Winder et al. 1999, Staats et al. 1999, de Brouwer \& Stal 2002, Bellinger et al. 2005). Mannose followed by glucuronic acid (Lombardi et al. 2005) and mannose associated with rhamnose (Lombardi \& Vieria 1999) was found to comprise a large proportion $(>40 \%)$ of the exopolysaccharides of 2 chlorococcalean green algae; in contrast, fucose and glucuronic acid predominated in strains of desmids (Domozych et al. 1993, Paulsen \& Vieira 1994). Growth status and environmental conditions can affect the composition of polysaccharides; however, HPLC data were in accordance with compositional patterns of seasonal samples. There were high concentrations of galacturonic acid in February and arabinose in August, which coincided with the dominance of cyanobacteria and diatoms, respectively. Culture studies on the dominant cyanobacteria in the Fiumicino WWTP revealed that production of arabinose is very low (Gloaguen et al. 1995, 1996); therefore, the high concentration of arabinose in our samples was most likely a result of diatom dominance.

$\mathrm{CD}$ characterization of biofilm exopolysaccharides in aqueous solution indicated that proteic moieties were absent from all tested fractions, demonstrating that saccharide extraction did not damage the cells. Ellipticity observed in the region of 200 to $250 \mathrm{~nm}$ was attributable to $\mathrm{n} \rightarrow \pi^{*}$ electronic transition of carbonyl groups, and confirmed the presence of uronic acids embedded in the chiral polysaccharide moiety. Temperature did not affect the CD spectra obtained: no conformational variation in the polysaccharide backbones was observed in any sample. This suggested that the overall polymeric conformation observed was a 'random coil', agreeing with previous studies of exopolysaccharides produced by some cyanobacteria and by the green macroalga Ulva sp.. Furthermore, this also highlighted a disordered sequence of saccharide units in the polymer chain (Cesàro et al. 1990, Paradossi et al. 1999, 2002, Bellezza et al. 2003). In contrast to temperature, $\mathrm{pH}$ did have an effect on the spectral qualities of biofilm exopolysaccharides. This may have resulted from the effect of the uronic moiety on the protonation equilibria in aqueous solutions driven by $\mathrm{pH}$ changes. As far as uronic moiety determination was concerned, $\mathrm{CD}$ data were qualitatively in agreement with the results from HPLC.

Cytochemical analysis distinguished among acidic, carboxylated and sulphated polysaccharides in the capsules, sheaths and mucilage of around 30 biofilm species. No changes in this pattern were observed among seasons. About $50 \%$ of cyanobacteria and $70 \%$ of diatoms reacted to staining for carboxylated polysaccharide, whereas green algae did not. Accordingly, it can be hypothesized that the carboxyl moiety revealed by $C D$ mainly resulted from the presence of cyanobacteria and diatoms. Sulphated residues were present in all diatoms and only in Lyngbya martensiana and Phormidium insigne of the cyanobacteria. The use of RR and $A B$ dyes revealed the presence of acidic groups in 6 epilithic cyanobacteria from Roman hypogea (Albertano \& Bellezza 2001, Bellezza et al. 2003) and in the sheath of Nostoc commune (Abdelahad \& Bazzichelli 1989). In addition, carboxylated and sulphated sugars were also evidenced in the EPS produced by Cylindrotheca closterium (de Brouwer et al. 2002) and in the exudates excreted by a Pleurosigma sp. strain in culture (Sdrigotti \& Talarico 1994).

Although investigation of the substratum colonization, biomass succession, and exopolysaccharide characteristics of phototrophic biofilms in WWTP waters has been seldom conducted to date, such studies are relevant to the exploitation of attached communities in bioremoval applications and ultimately contribute to realistic assessments of biofilm interactions with the environment (Barranguet et al. 2004).

Our data revealed that biofilms growing in the Fiumicino WWTP are rather common freshwater consortia, with widespread specific distribution and low biodiversity. A high productivity potential and ability to grow on a variety of artificial substrata facilitates easy handling of such communities in wastewater treatment systems, which can be based on cultures of selected organisms (Hoffman 1998). The negatively charged groups and conformational behavior of the exopolysaccharides of the biofilm matrix are important for the removal of residual nutrients and noxious cations in the treatment of wastewaters, and hence for the protection of receiving water bodies and the development of sustainable waste treatment alternatives to conventional physico-chemical methods.

Acknowledgements. We thank Dr. N. T. W. Ellwood for constructive criticism of the manuscript and the Agency for Environmental Protection of Aeroporti di Roma, Fiumicino (Italy) for fruitful collaboration and access to the plant. This research was partly conducted within the framework of EU project PHOBIA (QLK3-CT2002-01938).

\section{LITERATURE CITED}

Abdelahad N, Bazzichelli G (1989) A cytochemical investigation on the extracellular investment of Nostoc commune Vauch. (Cyanophyta). Arch Hydrobiol Suppl Algol Stud 57:437-447

Albertano P, Bellezza S (2001) Cytochemistry of cyanobacterial exopolymers in biofilms from Roman hypogea. Nova Hedwigia 123:501-518

Albertano P, Congestri R, Shubert LE (1999) Cyanobacterial biofilms in sewage treatment plants along the Tyrrhenian coast (Mediterranenan Sea), Italy. Arch Hydrobiol Suppl Algol Stud 94:13-24

Barranguet C, van Beusekom SAM, Veuger B, Neu TR, Man- 
ders EMM, Sinke JJ, Admiraal W (2004) Studying undisturbed autotrophic biofilms: still a technical challenge. Aquat Microb Ecol 34:1-9

Barranguet C, Veuger B, Van Beusekom SAM, Marian P, Sinke JJ, Admiral W (2005) Divergent composition of algal-bacterial biofilms developing under various external factors. Eur J Phycol 40:1-8

Battin TJ, Kaplan LA, Newbold JD, Hansen CME (2003) Contribution of microbial biofilms to ecosystem processes in stream mesocosm. Nature 426:439-441

Bellezza S, Paradossi G, De Philippis R, Albertano P (2003) Leptolyngbya strains from Roman hypogea: cytochemical and physico-chemical characterisation of exopolysaccharides. J Appl Phycol 15:193-200

Bellinger BJ, Abdullahi AS, Gretz MR, Underwood GJC (2005) Biofilm polymers: relationship between carbohydrate biopolymers from estuarine mudflats and unialgal cultures of benthic diatoms. Aquat Microb Ecol 38: $169-180$

Cesàro A, Liut G, Bertocchi C, Navarini L, Urbani R (1990) Physico-chemical properties of the exocellular polysaccharide from Cyanospira capsulata. Int J Biol Macromol 12:79-84

Congestri R, Sangiorgi VC, Albertano P (2003) Cytomorphology and distribution of periphytic cyanobacteria in one Italian WWTP. Arch Hydrobiol Suppl Algol Stud 109: 185-195

Congestri R, Cox EJ, Cavacini P, Albertano P (2005) Diatoms (Bacillariophyta) in phototrophic biofilms colonising an Italian wastewater treatment plant. Diatom Res 20: 241-255

Craggs RJ, Adey WH, Jenson KR, St. John MS, Green FB, Oswald WJ (1996) Phosphorus removal from wastewater using an algal turf scrubber. Water Sci Technol 33:191-198

Davis LS, Hoffmann JP, Cook PW (1990a) Seasonal succession of algal periphyton from a wastewater treatment facility. J Phycol 26:611-617

Davis LS, Hoffmann JP, Cook PW (1990b) Production and nutrient accumulation by periphyton in a wastewater treatment facility. J Phycol 26:617-623

de Brouwer JFC, Stal LJ (2002) Daily fluctuations of exopolymers in cultures of the benthic diatoms Cylindrotheca closterium and Nitzschia sp. (Bacillariophyceae). J Phycol 38:464-472

de Brouwer JFC, Wolfstein K, Stal LJ (2002) Physical characterization and diel dynamics of different fractions of extracellular polysaccharides in an axenic culture of a benthic diatom. Eur J Phycol 37:37-44

Decho AW (2000) Microbial biofilms in intertidal systems: an overview. Cont Shelf Res 20:1257-1273

De Philippis R, Vincenzini M (1998) Exocellular polysaccharides from cyanobacteria and their possible applications. FEMS Microbiol Rev 22:151-175

De Philippis R, Sili C, Paperi R, Vincenzini M (2001) Exopolysaccharide-producing cyanobacteria and their possible exploitation: a review. J Appl Phycol 13:293-299

de Winder B, Staats N, Stal LJ, Paterson DM (1999) Carbohydrate secretion by phototrophic communities in tidal sediments. J Sea Res 42:131-146

Domozych CR, Plante K, Blais P, Paliulis L, Domozych DS (1993) Mucilage processing and secretion in the green alga Closterium. I. Cytology and biochemistry. J Phycol 29:650-659

Gloaguen V, Morvan H, Hoffmann L (1995) Released and capsular polysaccharides of Oscillatoriaceae (Cyanophyceae, Cyanobacteria). Arch Hydrobiol Suppl Algol Stud 78:53-69
Gloaguen V, Vebret L, Morvan H (1996) Chemical composition of the capsular polymers of the blue-green algal mats of the thermal spring of Neris-les-Bain (France). Arch Hydrobiol Suppl Algol Stud 83:245-255

Hillebrand H, Dürselen CD, Kirschtel D, Pollingher U, Zohary $\mathrm{T}$ (1999) Biovolume calculation for pelagic and benthic microalgae. J Phycol 35:403-424

Hoagland KD, Rosowsky JR, Gretz MR, Roemer SC (1993) Diatom extracellular polymeric substances: functions, fine structure, chemistry, and physiology. J Phycol 29:537-566

Hoffmann JP (1998) Wastewater treatment with suspended and nonsuspended algae. J Phycol 34:757-763

Kaplan D, Christiaen D, Arad Malis S (1987) Chelating properties of extracellular polysaccharides from Chlorella spp. Appl Environ Microbiol 53:2953-2956

Lam PK, Lei A (1999) Colonization of periphytic algae on artificial substrates in a tropical stream. Diatom Res 14: $307-322$

Larson C, Passy SI (2005) Spectral fingerprinting of algal communities: a novel approach to biofilm analysis and biomonitoring. J Phycol 42:439-446

Lombardi A, Vieira AAH (1999) Lead- and copper-complexing extracellular ligands released by Kirchneriella aperta (Chlorococcales, Chlorophyta). Phycologia 38:283-288

Lombardi AT, Hidalgo TMR, Vieira AAH (2005) Copper complexing properties of dissolved organic materials exuded by the freshwater microalgae Scenedesmus acuminatus (Chlorophyceae). Chemosphere 60:453-459

Neu TR (1994) Biofilms and microbial mats. In: Krumbein WE, Paterson DM, Stal LJ (eds) Biostabilization of sediments. BIS Verlag, Oldenburg, p 9-15

Nicolaus B, Panico A, Lama L, Romano I, Manca MC, De Giulio A, Gambacorta A (1999) Chemical composition and production of exopolysaccharides from representative members of heterocystous and non-heterocystous cyanobacteria. Phytochemistry 52:639-647

Nultsch W, Hader DP (1988) Photomovement in motile microorganisms II. Photochem Photobiol 47:837-869

Otero A, Vincenzini M (2004) Nostoc (Cyanophyceae) goes nude: extracellular polysaccharides serve as a sink for reducing power under unbalanced $\mathrm{C} / \mathrm{N}$ metabolism. J Phycol 40:74-81

Paradossi G, Cavalieri F, Pizzoferrato L, Liquori AM (1999) A physico-chemical study on the polysaccharide ulvan from hot extraction of the macroalga Ulva. Int J Biol Macromol 25:309-315

Paradossi G, Cavalieri F, Chiessi E (2002) A conformational study on the algal polysaccharide ulvan. Macromolecules 35:6404-6411

Paulsen BS, Vieira AAH (1994) Structure of the capsular and extracellular polysaccharides producted by the desmid Spondylosium panduriforme (Chlorophyta). J Phycol 30: 638-641

Sdrigotti E, Talarico L (1994) Excretion of exudated by a diatom under culture. In: Marino D, Montresor M (eds) Proc 13th Int Diatom Symp. Biopress, Bristol, p 47-61

Shubert LE (2003) Nonmotile coccoid and colonial green algae. In: Wehr JD, Sheath RS (eds) Freshwater algae of North America: ecology and classification. Elsevier Science Publishers, New York, p 253-309

Sládečková A (1994) The role of periphyton in waste treatment technology. Verh Int Verein Theor Angew Limnol 25:1929-1932

Sládečková A, Matulová D (1998) Periphyton as bioeliminator. Verh Int Verein Limnol 26:1777-1780

Smith DJ, Underwood GJC (2000) The production of extracellular carbohydrates by estuarine benthic diatoms, the 
effects of growth phase and light and dark treatment. J Phycol 36:321-333

Staats N, de Winder B, Stal LJ, Mur LR (1999) Isolation and characterization of extracellular polysaccharides from the epipelic diatoms Cylindrotheca closterium and Navicula salinarum. Eur J Phycol 34:161-169

Stal LJ (2000) Cyanobacterial mats and stromatolites. In: Whitton BA, Potts M (eds) The ecology of cyanobacteria. Kluwer Academic, Dordrecht, p 61-120

Stal LJ, Defarge C (2005) Structure and dynamics of exopolymers in an intertidal diatom biofilm. Geomicrobiol $\mathrm{J} 22$ : 341-352

Stevenson RJ (1996) An introduction to algal ecology in freshwater benthic habitats. In: Stevenson RJ, Bothwell ML, Lowe RL (eds) Algal ecology. Freshwater benthic ecosystems. Academic Press, San Diego, CA, p 3-30

Sutherland IW (2001) Biofilm exopolysaccharides: a strong and sticky framework. Microbiology 147:3-9

Thornton DCO (2002) Diatom aggregation in the sea: mechanisms and ecological implications. Eur J Phycol 37: 149-161

Tuji A (2000a) Observation of development processes in loosely attached diatom (Bacillariophyceae) communities. Phycol Res 48:75-84

Tuji A (2000b) The effect of irradiance on growth of different forms of freshwater diatoms: implications for succession in

Editorial responsibility: Staffan Kjelleberg,

Sydney, New South Wales, Australia attached diatom communities. J Phycol 36:659-661

Underwood GJC, Boulcott M, Raines CA, Waldron K (2004) Enviromental effects on exopolymer production by marine benthic diatoms: dynamics, changes in composition, and pathways of production. J Phycol 40:293-304

van den Hoek C, Mann DG, Jahns HM (1995) Algae: an introduction to phycology. Cambridge University Press, Cambridge

Vincenzini M, De Philippis R, Sili C, Materassi R (1990a) Studies on exopolysaccharide release by diazotrophic batch cultures of Cyanospira capsulata. Appl Microbiol Biotechnol 34:392-396

Vincenzini M, De Philippis R, Sili C, Materassi R (1990b) A novel exopolysaccharide from a filamentous cyanobacterium: production, chemical characterisation and rheological properties. In: Dawes EA (ed) Novel biodegradabile microbial polymers. Kluwer Academic, Dordrecht, p 295-310

Wiggli M, Smallcombe A, Bachofen R (1999) Reflectance spectroscopy and laser confocal microscopy as tools in an ecophysiological study of microbial mats in an alpine bog pond. J Microbiol Methods 34:173-182

Wingender J, Neu TR, Flemming HC (1999) What are bacterial extracellular polymeric substances? In: Wingender $\mathrm{J}$, Neu TR, Flemming HC (eds) Microbial extracellular polymeric substances, Springer Verlag, Berlin, p 1-19

Submitted: May 26, 2006; Accepted: September 4, 2006

Proofs received from author(s): December 11, 2006 